\title{
Anti-inflammatory and antinociceptive activities of methanolic extract from red seaweed Dichotomaria obtusata
}

\author{
Neivys García Delgado", ${ }^{1, *}$, Ana Iris Frías Vázquez², Hiran Cabrera Sánchez ${ }^{3}$, Roberto Menéndez \\ Soto del Valle', Yusvel Sierra Gómez ${ }^{4}$, Ana María Suárez Alfonso ${ }^{5}$
}

\begin{abstract}
${ }^{1}$ Department of Pharmacology, Center of Marine Bioproducts (CEBIMAR), Havana, Cuba, ${ }^{2}$ Department of Human and Animal Biology, Faculty of Biology, University of Havana, Cuba, ${ }^{3}$ Pharmacology Central Laboratory, Faculty of Medical Sciences Dr. Salvador Allende, Havana, Cuba, ${ }^{4}$ Center for Protein Studies, Faculty of Biology, University of Havana, Cuba, ${ }^{5}$ Center of Marine Researches, University of Havana, Cuba
\end{abstract}

\begin{abstract}
The aim of the present work was to investigate the anti-inflammatory and antinociceptive effects of methanolic extract from $D$. obtusata using classic models in mice (croton oil-induced ear edema and acetic acid-induced writhing) and a phospholipase $\mathrm{A}_{2}$ activity test. Qualitative analysis of the chemical composition of seaweed was also determined by extraction with solvents of increasing polarity and precipitation and color tests. Results of qualitative chemical study showed the presence of lactonic and phenolic compounds, reduced carbohydrates, other sugars, flavonoids, fatty compounds, triterpenes and steroids. The extract inhibited mouse ear edema in a dose-dependent manner with an efficacy higher than $90 \%$ and a mean effective dose of $4.87 \mu \mathrm{g} / \mathrm{ear}$, while intraperitoneal administration presented a moderate activity. The extract did not inhibit phospholipase $\mathrm{A}_{2}$ activity. In the writhing test, the intraperitoneal administration of the extract showed a strong antinociceptive activity $(80.2 \%)$, while the oral route showed a lower efficacy. In conclusion, this study demonstrated the anti-inflammatory and antinociceptive effects of methanol extract of D. obtusata in experimental models, suggesting its therapeutic potential in the treatment of peripheral painful and/or inflammatory pathologies.
\end{abstract}

Uniterms: Dichotomaria obtusata/pharmacognosy. Dichotomaria obtusata/anti-inflammatory activity. Dichotomaria obtusata/antinociceptive activity. Mouse ear edema test. Writhing test.

O objetivo do presente trabalho foi investigar os efeitos antiinflamatórios e antinociceptivos de um extrato metanólico de D. obtusata, utilizando modelos clássicos em ratos (teste do edema de orelha induzido por óleo de cróton e teste de contorções induzidas por ácido acético) e um teste de atividade de fosfolipase $\mathrm{A}_{2}$. A análise qualitativa da composição química das algas foi também determinada através de extração com solventes de polaridade crescente e testes de precipitação e cor. Os resultados do estudo de química qualitativa mostraram a presença de compostos lactônicos e fenólicos, hidratos de carbono reduzidos e outros açúcares, flavonoides, compostos graxos, triterpenos e esteroides. O extrato inibiu o edema de orelha dos ratos de um modo dependente da dose com eficácia superior a $90 \%$ e dose média efetiva de $4.87 \mu \mathrm{g} /$ orelha, enquanto a administração intraperitoneal apresentou atividade moderada. $\mathrm{O}$ extrato não inibiu a atividade da fosfolipase $\mathrm{A}_{2}$. No teste de contorção, a administração intraperitoneal do extrato mostrou forte atividade antinociceptiva (80,2\%), enquanto a administração oral mostrou menor eficácia. Em conclusão, este estudo demonstrou os efeitos antiinflamatórios e antinociceptivos do extrato metanólico de D. obtusata em modelos experimentais, sugerindo seu potencial terapêutico no tratamento de patologias dolorosas periféricas e/ou inflamatórias.

Unitermos: Dichotomaria obtusata/farmacognosia. Dichotomaria obtusata/atividade antiinflamatória. Dichotomaria obtusata/atividade antinociceptiva. Teste do edema de orelha. Teste de contorções.

\footnotetext{
"Correspondence: N. G. Delgado. Department of Pharmacology, Center of Marine Bioproducts (CEBIMAR), AMA, CITMA. Loma y 37, Alturas del Vedado, Plaza de la Revolución, 10400 - Havana, Cuba. E-mail: neivys@cebimar.cu; neivysgd8684@gmail.com
} 


\section{INTRODUCTION}

Marine environment may contain over $80 \%$ of world's species of plants and animals (Kumar, Xi-rong, 2004). Particularly, seaweeds have been of great interest for humans as marine food sources since old times (Nisizawa et al., 1987). Nowadays, these organisms represent a promising source of useful products awaiting discovery for the prevention or treatment of several pathologies (Faulkner, 2002). Ecological pressures, including fight for space and predation, have contributed to the evolution of secondary metabolites with diverse pharmacological properties. In fact, the discovery of metabolites with biological activities from seaweeds has increased significantly in the past three decades (Smit, 2004).

On the other hand, inflammation is a defensive reaction of organisms to antigenic stimulation or physical injuries. This response involves the activation of complex metabolic pathways and the intervention of chemical and cellular mediators (Pruzanskim, Vadas, 1991; Abbas et al., 2008). Nevertheless, an exacerbated response can conduce to the development of multiple pathologies, including rheumatoid arthritis, acute gout, asthma, neurodegenerative diseases and cancer (Kazłowska et al., 2010). Furthermore, pain is a classic sign of this inflammatory response (Flórez, Reig, 1994).

Pharmaceutical anti-inflammatory drugs are generally used to treat inflammation and pain. In general, these drugs reduce inflammatory response by suppressing the production of pro-inflammatory mediators, which are involved in the pathogenesis of inflammatory diseases (Guslandi, 1998). Nevertheless, reports on the increased risk of digestive, cardiovascular and renal diseases with long-term use of several non-steroidal anti-inflammatory drugs and the serious systemic side effects of glucocorticoids, have raised concerns about using the drugs (Jugdutt, 2007). To overcome this limitation, a considerable amount of researches have promoted the discovery and development of new bioactive natural products with antiinflammatory and antinociceptive properties which do not show any side effects.

An increasing number of studies have demonstrated that certain extracts and compounds from seaweeds have potential anti-inflammatory uses. For example, Ganovski et al. in 1979 reported the anti-inflammatory effect of an aqueous extract from Cystosina barbata, Ulva lactuca and Zostera nona. Also, Payá et al. in 1993 studied the antiinflammatory potential of methanol and dichloromethane extracts of seven species of seaweeds. A group of inhibitors of phospholipase $\mathrm{A}_{2}$ were isolated from different microalgae (Mayer et al., 1993). Recently, other metabolites with anti- inflammatory activity have been obtained from seaweeds, including a glycosterol (Awad, 2000), a phlorotannin (Sugiura et al., 2006), polyphenols (Jung et al., 2009; El Gamal, 2010) and polysaccharides (Ananthi et al., 2010). Moreover, various seaweeds have antinociceptive properties (Anca et al., 1993; Guzmán et al., 2001; Viana et al., 2002).

Dichotomaria obtusata (J. Ellis, Solander) Lamarck, a red seaweed found in tropical and subtropical shores, is one of the most common species of the phylum Rhodophyta (Suárez, 2005). This species has been used in a small number of biological studies. We have recently reported the intraperitoneal anti-inflammatory and antinociceptive properties of aqueous extract of D. obtusata in two classic animal models (Frías et al., 2011). However, anti-inflammatory efficacy of the aqueous extract was limited and the mechanisms of action have not been examined yet. In order to obtain a greater efficacy, a new extract of this seaweed was prepared. Therefore, the aim of the current study was to evaluate the anti-inflammatory and antinociceptive potential of methanolic extract of D. obtusata employing different routes of administration. Before that, we have carried out a preliminary acute toxicological study of our extract with the purpose of knowing the safety of the working material. Also, one of the possible mechanisms of action of bioactive components of the extract was investigated in an in vitro assay. We present novel anti-inflammatory and antinociceptive activities of red seaweed $D$. obtusata.

\section{MATERIALS AND METHODS}

\section{Drugs and reagents}

Tested drugs (indomethacin, dexamethasone, acetylsalicylic acid) and reagent (croton oil) were purchased from Sigma Chemicals.

\section{Material}

The red alga Dichotomaria obtusata was collected at Jaimanitas Beach, Havana, in November 2008, and was identified by Dr. Ana María Suarez, researcher of the Center of Marine Researches, University of Havana. A voucher specimen was deposited at the Herbarium from Center of Marine Researches under the acquisition number r-189. Specimens were washed with common water, dried at room temperature and kept at $4{ }^{\circ} \mathrm{C}$ until the obtaining of the methanolic extract.

\section{Compositional analysis of $D$. obtusata}

The qualitative analysis of the chemical composition 
of D. obtusata was conducted according to Chabra's method (Chabra et al., 1984), which is based on extraction with solvents of increasing polarity (dichloromethane, ethanol and water) and tests of precipitation and color solutions.

\section{Preparation of the methanolic extract}

Specimens of D. obtusata (50 g) were dissolved in $500 \mathrm{~mL}$ of methanol and soaked at room temperature during 8 hours. The methanol extract was concentrated in a rotary evaporator (BUCHI, Model B48C) and stored at $4{ }^{\circ} \mathrm{C}$ until its use.

\section{Animals}

All animal experiments were conducted according to the Guide for the Care and Use of Laboratory Animals of the Center for Laboratory Animals Production (CENPALAB), Cuba. For one week before the experiments, male Cenpalab mice: OF-1 weighing 23-25 g were maintained in ventilated plastic cages in a soundproofed room at $22{ }^{\circ} \mathrm{C}$, with an artificial 12:12 h light:dark cycle. Food and sterile water were supplied ad libitum. Animals were randomized into treatment groups and deprived of food and water during the experiment.

\section{Acute Toxicity Study}

The acute toxicity study of the methanolic extract of D. obtusata was carried out according to the acutetoxic-class method as alternative to the $L D_{50}$ test (Schlede et al., 1992). Graded doses (25, 200 and $2000 \mathrm{mg} / \mathrm{kg})$ of methanolic extract were administered intraperitoneally to various groups, each group containing six mice. On the first hour after administration, the animals were evaluated every 10 minutes for any changes in respiratory frequency, writhing, piloerection, spontaneous motor activity, etc. Animals were observed up to 24 hours for any mortality.

\section{Mouse ear edema test}

All procedures of mouse ear edema bioassay were carried out following the established method of Tubaro et al. (1986). Edema was induced in right ear of each mouse by the topical application, to both the inner and outer surfaces, of $10 \mu \mathrm{L}$ of a $0.47 \%$ croton oil solution in acetone to induce inflammation, and the same volume of acetone was applied to the left ear. Methanolic extract dissolved in ethanol was administered topically $\left(0.5 \times 10^{-3}, 1 \times 10^{-3}\right.$, $1.5 \times 10^{-3}, 7.5 \times 10^{-3}, 15 \times 10^{-3}, 30 \times 10^{-3}, 0.5,1$ and $\left.2 \mathrm{mg} / \mathrm{ear}\right)$ and intraperitoneally (i.p.) $(12.5,25,50$ and $100 \mathrm{mg} / \mathrm{kg})$ simultaneously and 30 min before croton oil application, respectively. As positive controls for comparative purposes, other groups of animals were treated with indomethacin $(0.5 \mathrm{mg} / \mathrm{ear}$ and $10 \mathrm{mg} / \mathrm{kg})$ dissolved in $5 \%$ $\mathrm{NaHCO}_{3}$ and dexamethasone $(0.1 \mathrm{mg} /$ ear and $0.5 \mathrm{mg} / \mathrm{kg})$, following the same conditions of extract administration. Five hours after croton oil application, the animals were sacrificed by cervical dislocation and the ears were cut off. In all experiments, a disk was cut from the middle part of each ear using a punch $7 \mathrm{~mm}$ in diameter. The edema size was determined in relation to the weight of untreated left ear and percentage of inhibition was calculated using the following expression:

$$
\% \text { Inhibition }=(\Delta \mathrm{Pc}-\Delta \mathrm{Pt}) / 100 \times \Delta \mathrm{Pc}
$$

where: $\Delta \mathrm{Pc} \rightarrow$ mean weight variation in the control group; $\Delta \mathrm{Pt} \rightarrow$ mean weight variation in the treated group.

\section{Phospholipase $A_{2}$ activity test}

The ability of methanolic extract to inhibit phospholipase $\mathrm{A}_{2}$ was evaluated according to the indirect radial hemolysis in agar plate method proposed by Gutiérrez et al., in 1988. A Petri plate was prepared with agar containing egg yolks (substrate of phospholipids), calcium chloride (enzymatic cofactor), sodium azide (preservative) and human erythrocytes for visualizing the effect. Methanolic extract $(2.5,5$ and $10 \mathrm{mg} / \mathrm{mL})$ was dissolved in PBS (0.12 M NaCl, $\left.0.04 \mathrm{M} \mathrm{NaHPO}_{4}^{2-}, \mathrm{pH} 7.2\right)$ and applied by triplicate in the holes (6-mm diameter) made in the plate. The phospholipase $\mathrm{A}_{2}$ purified from sea anemone Condylactis gigantea was used as control. This enzyme was donated by the Center for Protein Studies, University of Havana. The plate was maintained at $37^{\circ} \mathrm{C}$ by 12 hours. The enzymatic activity was determined by the presence of halos as an indicative of hemolysis.

\section{Acetic acid-induced writhing test}

The acetic acid-induced writhing test was conducted as originally described by Koster et al in 1959. Mice were randomly distributed in control and test groups of ten animals each. In this test, an intraperitoneal injection of acetic acid $(0.8 \%, 10 \mathrm{ml} / \mathrm{kg}$ b.w.) was given 30 and $60 \mathrm{~min}$ after the i.p. $(12.5,25,50$ and $100 \mathrm{mg} / \mathrm{kg})$ and oral $(100$, 200,400 and $800 \mathrm{mg} / \mathrm{kg}$ ) administrations of test extract, respectively. Also, the reference drug acetylsalicylic acid $(68 \mathrm{mg} / \mathrm{kg})$ was administrated by oral route 1 hour before acetic acid injection, and control group was treated with sterile $0.9 \%$ saline solution. Following that, the number of 
writhing movements in the mice was counted for $20 \mathrm{~min}$. The antinociceptive activity of the methanolic extract was expressed as percentage of pain reduction in treated mice with respect to control, according to the relation:

$$
\% \text { Reduction }=(\Delta \mathrm{Cc}-\Delta \mathrm{Ct}) / 100 \times \Delta \mathrm{Cc}
$$

where: $\Delta \mathrm{Cc} \rightarrow$ mean of number of writhes of control group (vehicle-injected animals); $\Delta \mathrm{Ct} \rightarrow$ mean of number of writhes in the treated group.

\section{Statistical analysis}

Data are expressed as mean \pm SEM. One way analysis of variance (ANOVA) was applied for the analysis of results using software packages Statistica (version 7.0) and Past (version 1.99). P-values less than 0.05 and 0.001 were considered significantly different for Tukey-Kramer and Bonferroni multiple comparison tests, respectively.

\section{RESULTS}

\section{Compositional analysis of D. obtusata}

The results of the qualitative chemical study of $D$. obtusata (Table I) showed the notable presence of lactonic and phenolic compounds, reduced carbohydrates and other sugars. However, the presence of flavonoids, fatty compounds, triterpenes and steroids was low.

\section{Acute Toxicity Study}

Acute toxicity results of the intraperitoneal administration of methanolic extract are presented in Table II. As can be appreciated, no mortality of animals was observed after 24 hours of administration of extract at 25, 200 and $2000 \mathrm{mg} / \mathrm{kg}$. The most significant signs of toxicity were swing and writhing, which were presented at all doses. Swing showed a percentage of appearance superior at $65 \%$. Also, the periods of latency of appearance of these signs were dose-dependent at doses of 25 and $200 \mathrm{mg} / \mathrm{kg}$. However, this parameter decreased at $2000 \mathrm{mg} / \mathrm{kg}$. In addition, the stoop of back train was observed at doses of $200 \mathrm{mg} / \mathrm{kg}$ (33.3\%) and $2000 \mathrm{mg} / \mathrm{kg}(66.7 \%)$. Finally, a sedative effect (33.3\% of appearance and $75 \mathrm{sec}$ of latency) and the increase of respiratory frequency $(100 \%$ of appearance and $56 \mathrm{sec}$ of latency) were observed in animals administered with the maximum dose of extract.

\section{Croton oil-induced ear edema test}

Table III shows the anti-inflammatory effect of

TABLE I - Qualitative phytochemical analysis of Dichotomaria obtusata

\begin{tabular}{|c|c|c|c|}
\hline \multirow{2}{*}{ Test } & \multicolumn{3}{|c|}{ Extracts } \\
\hline & Dichloromethane & Ethanolic & Aqueous \\
\hline $\begin{array}{l}\text { Sudan (Fatty compounds) } \\
\text { (F) }\end{array}$ & + & & \\
\hline Dragendorff (Alkaloids) & - & - & - \\
\hline Baljet (Lactonic compounds) & ++ & ++ & +++ \\
\hline Ferric Hydroxamate (Coumarins) & - & & - \\
\hline Borntrager (Quinones) & & - & \\
\hline Liebermann-Burchard (Triterpenes and steroids) & + & + & + \\
\hline Catechines & & - & \\
\hline Fehling (Reduced carbohydrates) & & - & +++ \\
\hline Foam (Triterpene and steroid saponins) & & +++ & - \\
\hline Ferric chloride (Phenols and tannins) & & ++ & ++ \\
\hline Ninhydrin (Amino acids) & & + & \\
\hline Shinoda (Flavonoids) & & + & \\
\hline Kedde (Cardiotonic glycosides) & - & - & - \\
\hline Anthocyanidins (Flavonoids with structure C6-C3-C6) & & + & \\
\hline Mucilages (Polysaccharides) & & & ++ \\
\hline Resins & & - & \\
\hline Molish (Carbohydrates) & & + & ++ \\
\hline
\end{tabular}

Legend: - negative reaction; + weak reaction; ++ half reaction; +++strong reaction. 
TABLE II - Percentage of mortality and signs of toxicity observed in OF-1 mice after i.p. administration of methanolic extract from D. obtusata $(\mathrm{n}=6$ animals/dose)

\begin{tabular}{lcccc}
\hline Doses $(\mathrm{mg} / \mathrm{kg})$ & Mortality (\%) & Signs of Toxicity & Appearance of signs (\%) & Latency (seconds; mean \pm SEM) \\
\hline 25 & 0 & Swing & 66.7 & $58,8 \pm 12,6$ \\
& Writhing & 83.3 & $73,2 \pm 6,1$ \\
\hline 200 & Swing & 100 & $21,8 \pm 2,0$ \\
& Writhing & 100 & $39,2 \pm 4,9$ \\
& & Stoop of back train & 33.3 & $45,5 \pm 0,5$ \\
\hline 2000 & Swing & 66.7 & $27,5 \pm 8,0$ \\
& Writhing & 50 & $51,7 \pm 4,4$ \\
& 0 & 66.7 & $31,5 \pm 5,3$ \\
& & Stoop of back train & 100 & $55,8 \pm 17,3$ \\
& Increase of respiratory & & \\
& frequency & 33.3 & $75,0 \pm 45,0$ \\
& Sedative effect &
\end{tabular}

topical administration of methanolic extract $\left(0.5 \times 10^{-3}\right.$, $1 \times 10^{-3}, 1.5 \times 10^{-3}, 7.5 \times 10^{-3}, 15 \times 10^{-3}, 30 \times 10^{-3}, 0.5,1$ and $2 \mathrm{mg}$ /ear) on croton oil-induced ear edema in mice. The ear edema in control group, five hours after croton oil application, was $18.25 \pm 0.23 \mathrm{mg}$. All doses of extract decreased significantly $(\mathrm{p}<0.0001)$ the action of the irritating agent except the dose of $0.5 \times 10^{-3} \mathrm{mg} /$ ear.

As can be seen, five of the evaluated doses exerted a significant inhibition of edema $(>50 \%)$. The extract at $1 \mathrm{mg} /$ ear showed the greatest inhibition of edema

TABLE III - Effect of topical administration of methanolic extract from D. obtusata on croton oil-induced ear edema in mice ( $\mathrm{n}=6$ animals/doses)

\begin{tabular}{lcc}
\hline Doses (mg/ear) & $\begin{array}{c}\text { Edema }(\mathrm{mg}) \\
(\text { mean } \pm \text { SEM) }\end{array}$ & $\begin{array}{c}\text { Edema reduction } \\
(\%)\end{array}$ \\
\hline Control & $18.25 \pm 0.23$ & \\
$0,5 \times 10^{-3}$ & $18.37 \pm 1.03^{*}$ & 0 \\
$1 \times 10^{-3}$ & $17.62 \pm 0.85^{* *}$ & 3.45 \\
$1,5 \times 10^{-3}$ & $15.52 \pm 0.72 * *$ & 14.96 \\
$7,5 \times 10^{-3}$ & $9.32 \pm 0.52 * *$ & 48.93 \\
0.015 & $8.05 \pm 0.97 * *$ & 55.89 \\
0.03 & $5.02 \pm 0.60^{* *}$ & 72.49 \\
0.5 & $2.83 \pm 0.65^{* *}$ & 84.49 \\
1 & $1.38 \pm 0.43^{* *}$ & 92.44 \\
2 & $3.2 \pm 0.18^{* *}$ & 82.47 \\
Dexamethasone $(0.1)$ & $2.17 \pm 0.26^{*}$ & 88.11 \\
Indomethacin $(0.5)$ & $7.12 \pm 0.60^{*}$ & 60.99 \\
\hline * $<<0.0001$ compared with control; **p $<0.0001$ compared \\
with indomethacin and dexamethasone (Bonferroni’s test)
\end{tabular}

(92.44\%), which was similar to reference drug dexamethasone $(88.11 \%$ at $0.1 \mathrm{mg} / \mathrm{ear})$ and far superior to indomethacin $(60.99 \%$ at $0.5 \mathrm{mg} / \mathrm{ear})$.

Methanolic extract showed a dose-dependent antiinflammatory effect. Figure 1 illustrates the dose-response relation of topical application of extract. The behavior of curve indicates that the apparent maximum dose is $1 \mathrm{mg} / \mathrm{ear}$. Also, the Mean Effective Dose (dose inducing a $50 \%$ edema inhibition, $\mathrm{ED}_{50}$ ) was calculated, which was $4.87 \mu \mathrm{g} / \mathrm{ear}$.

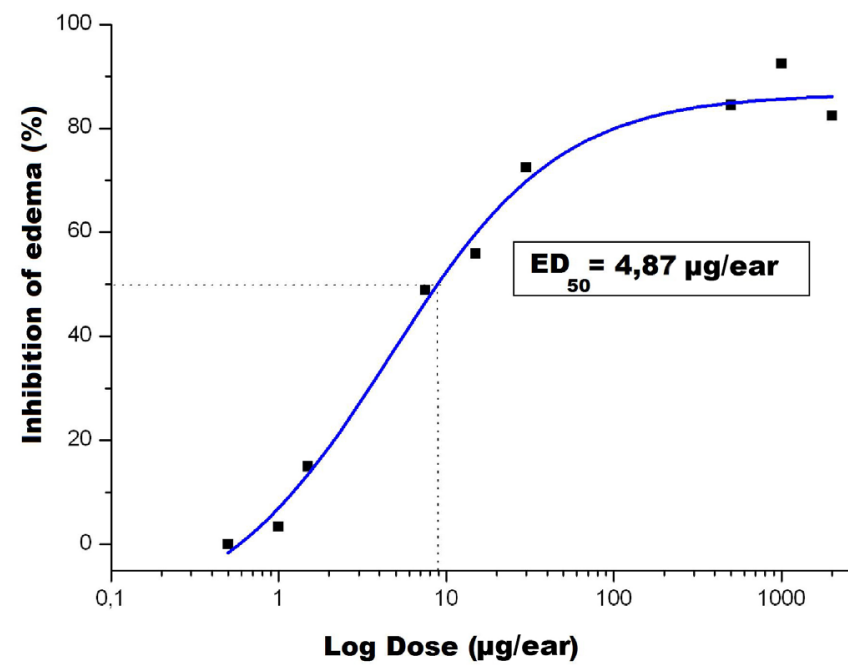

FIGURE 1 - Dose-response relation of topical application of methanolic extract from $D$. obtusata.

In the same way, the anti-inflammatory activity of extract was evaluated using the systemic administration (i.p.). The results obtained at different doses of extract 


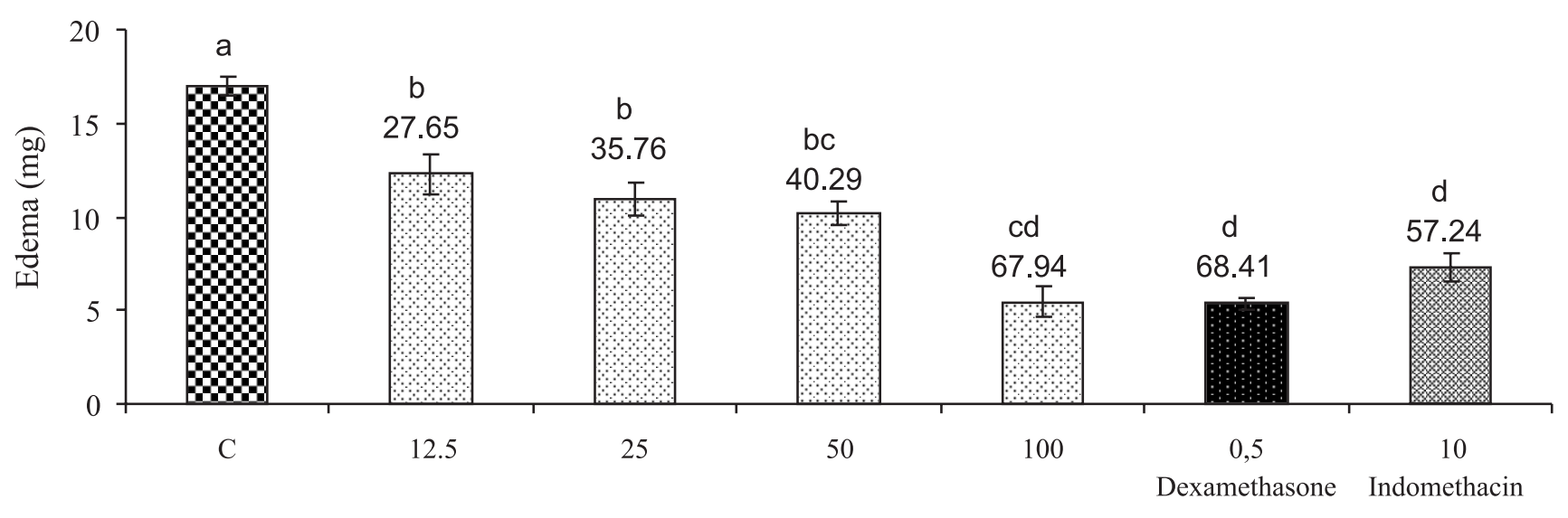

Doses $(\mathrm{mg} / \mathrm{kg})$

FIGURE 2 - Effect of intraperitoneal administration of methanolic extract from D. obtusata on croton oil-induced ear edema in mice $(\mathrm{n}=6$ animals/dose).

$(12.5,25,50$ and $100 \mathrm{mg} / \mathrm{kg})$ are shown in Figure 2. All groups of treatment were able to decrease significantly $(\mathrm{p}<0.05)$ the croton oil-induced ear edema compared to control group (which received $0.9 \%$ saline solution). Similar to topical application, the i.p. administration of extract inhibited this edema in a dose-dependent manner. The maximum inhibition was $67.94 \%$ at dose of $100 \mathrm{mg} / \mathrm{kg}$, which was not different from response of reference drugs indomethacin (57.24\%) and dexamethasone (68.41\%).

\section{Phospholipase $A_{2}$ activity test}

One of the probable mechanisms of action of antiinflammatory compounds is mediated by the inhibition of phospholipase activity. For this reason, methanolic extract of D. obtusata was tested for a possible inhibitory activity of phospholipase $\mathrm{A}_{2}$, using the indirect radial hemolysis in agar plate method. The effect of extract $(2.5,5$ and $10 \mathrm{mg} / \mathrm{mL}$ ) in this assay is shown in Figure 3. The presence of halos of hemolysis around the holes of the plate, where extract and control phospholipase $\mathrm{A}_{2}$ were applied, indicates the extract did not inhibit the enzymatic activity. Phospholipase $\mathrm{A}_{2}$ hydrolyzes the phospholipids of egg yolk, which are liberated into medium as fatty acids and glycerophospholipids. After that, the $\mathrm{pH}$ of culture medium decreases and this promotes the lysis of erythrocytes and the appearance of halos of hemolysis.

\section{Acetic acid-induced writhing test}

Antinociceptive activity of methanolic extract was examined using writhing test. Intraperitoneal administration of the extract at the doses of $12.5,25,50$ or $100 \mathrm{mg} / \mathrm{kg}$

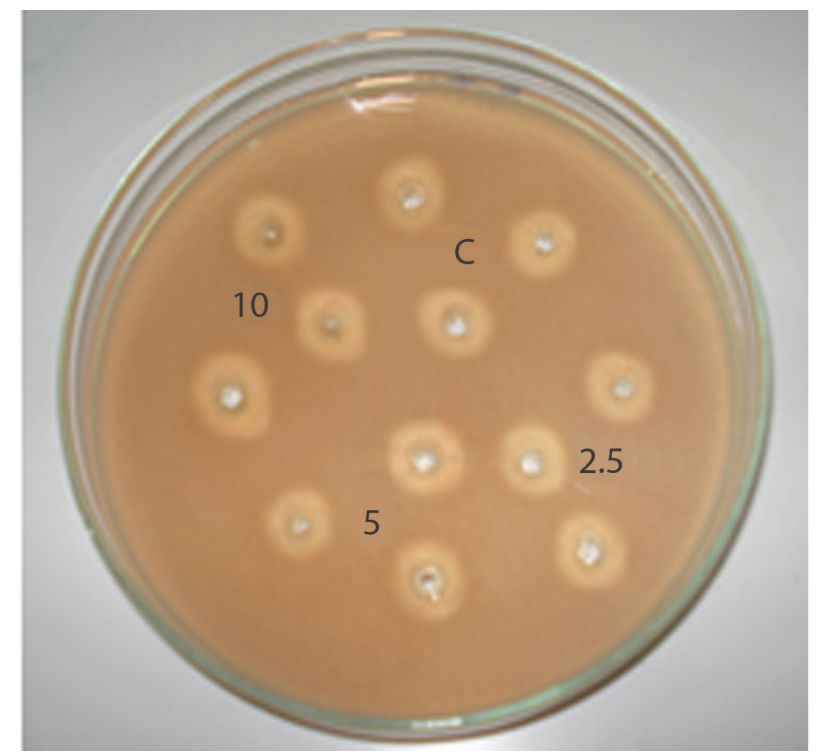

FIGURE 3 - Effect of methanolic extract from D. obtusata (10, 5 and $2.5 \mathrm{mg} / \mathrm{mL}$ ) on phospholipase $\mathrm{A}_{2}$ activity.

body weight decreased significantly $(\mathrm{p}<0.0001)$ the action of acetic acid used to induce writhes in mice, in comparison to the control animals that received only $0.9 \%$ saline solution.

The effects of i.p.-administered extract were dosedependent. There results can be seen in Figure 4. Treatment with $12.5 \mathrm{mg} / \mathrm{kg}$ reduced the number of writhes in $47.72 \%$, which was further decreased in $80.2 \%$ with $100 \mathrm{mg} / \mathrm{kg}$ of the extract. The reference analgesic drug, acetylsalicylic acid $(68 \mathrm{mg} / \mathrm{kg})$ caused inhibition of writhes in $49.49 \%$.

The results of the acetic acid-induced writhing responses in mice one hour after oral administration of 


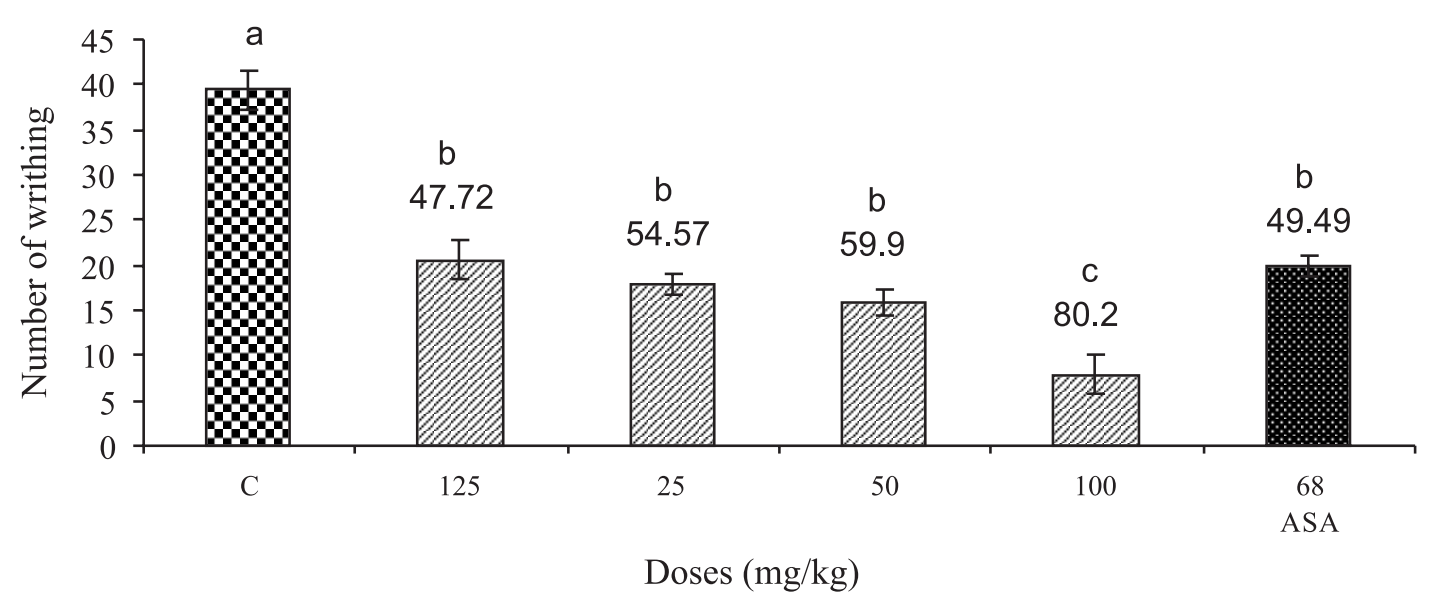

FIGURE 4 - Effect of intraperitoneal administration of methanol extract from D. obtusata on acetic acid-induced writhing in mice $(\mathrm{n}=10$ animals/dose). ASA: acetylsalicylic acid (reference drug).

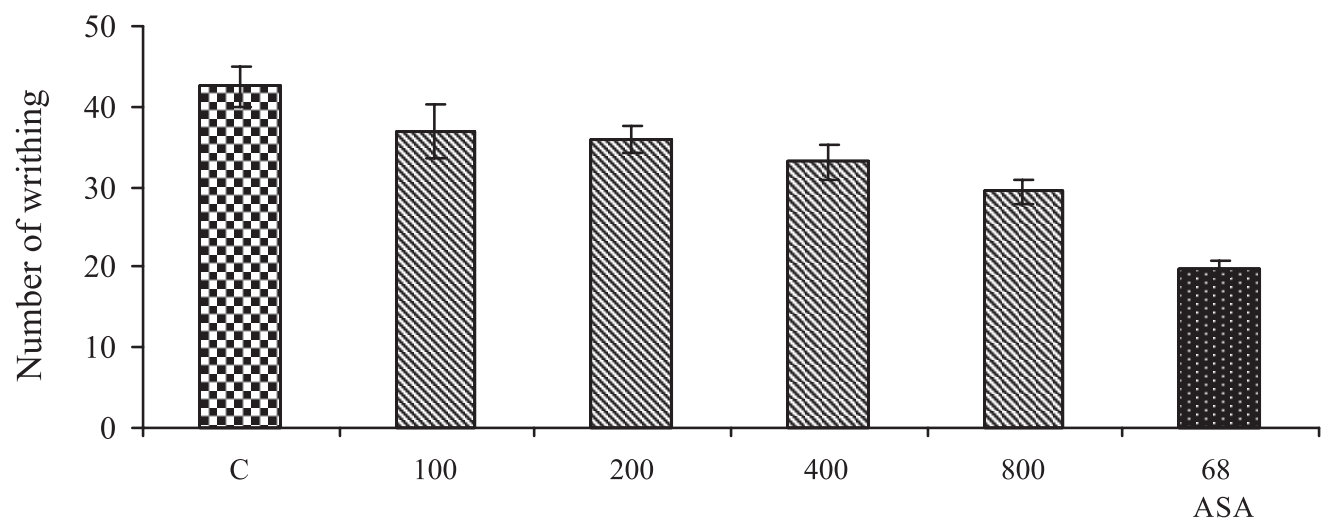

Doses $(\mathrm{mg} / \mathrm{kg})$

FIGURE 5 - Effect of oral administration of methanol extract from D. obtusata on acetic acid-induced writhing in mice ( $\mathrm{n}=10$ animals/dose). ASA: acetylsalicylic acid (reference drug).

the extract are presented in Figure 5. In this case, only the maximum dose of the extract $(800 \mathrm{mg} / \mathrm{kg})$ had a clear antinociceptive effect, with a significant reduction of the number of writhes $(p<0.05)$ compared to control animals. The percentage of inhibition of writhes at this dose was $30.87 \%$, which was lower than the reference drug $(53.25 \%)$.

\section{DISCUSSION}

The purpose of this paper was to evaluate antiinflammatory and antinociceptive effects of methanolic extract from the red seaweed Dichotomaria obtusata using classic models in mice and an in vitro test.

Red seaweeds are considered the most important source of many biologically active metabolites in comparison to other algal classes (El Gamal, 2010). As a first step toward identifying the major chemical groups present in D. obtusata, we have developed a qualitative chemical study of its composition. Results showed the presence of lactonic and phenolic compounds, flavonoids, fatty compounds, triterpenes, steroids, reduced carbohydrates and other sugars. In agreement with our results, Frías et $a l$. in 2011 demonstrated the presence of carbohydrates, proteins, triterpenes and steroids in the aqueous extract from D. obtusata. Some of these compounds, such as phenols, terpenes, polysaccharides and steroids, have been reported to possess anti-inflammatory and antinociceptive effects (Silva, Scheuer, 1980; Chong, Parish, 1985; Awad, 2000; Lucas et al., 2003; Rodríguez et al., 2004; Jung et al., 2009).

On the other hand, it is known that the possible therapeutic application of a new drug requires the evaluation of its preclinical pharmacological activities and studies of safety. Taking into account these considerations, we have evaluated the lethality of the methanolic extract using an 
alternative acute toxicity test. The animals intraperitoneally administered showed some signs of toxicity (swing and writhing) at all tested doses. Other signs appeared at the highest dose (increased respiratory frequency and sedative effect). However, the animals in all groups survived, signifying the absence of lethality under our experimental conditions. This extract was much less toxic than aqueous extract from the same seaweed (unpublished data), suggesting that the majority of toxic metabolites from $D$. obtusata are of polar nature.

In a first set of pharmacological experiments, we investigated the effects of the extract on croton oil-induced ear edema using i.p. and topic single administrations. The extract dose dependently reduced edema formation and showed potency similar to that of reference drugs by topical route. In fact, its maximum effect was superior to $90 \%$ and its $\mathrm{ID}_{50}$ value was $4.87 \mu \mathrm{g} / \mathrm{ear}$. Taking into account that the extract is a complex mixture of several components, these values indicate its elevated pharmacological efficacy and potency.

Topical application of croton oil produced a longerlasting edema associated with marked influx of neutrophils and predominant formation of LTB4 along with significant changes in levels of TXB2. Also, earlier studies have revealed that histamine, serotonin and prostaglandins could play a role in the development of edema induced by this irritant agent (Gabor; Razga, 1990; Blazso, Gabor, 1994). The advantages of this model include its good predictive value for screening topical anti-inflammatory activity and its sensitivity to both steroidal and non-steroidal drugs. Nevertheless, this sensitivity is dependent on the time course of the response (Tubaro et al., 1986).

Although the extract intraperitoneally administered was able to reduce the croton oil-induced ear edema at all evaluated doses, the efficacy was lower than that of topical route. Here, bioavailability factor might also be involved, because after topical application a large concentration of the extract could be available to the target tissues whereas this could be limited with the systemic administration. This is in agreement with previous studies of our group on the aqueous extract of this seaweed, which demonstrated a maximum anti-inflammatory activity greater than $65 \%$ in TPA-induced ear edema in mice (Frías et al., 2011).

The results obtained in this acute inflammation model and the topical efficacy of the extract compared to dexamethasone suggest an interaction with metabolites of the arachidonic acid pathway, mediated mainly by phospholipase $\mathrm{A}_{2}$ (PLA2) and cyclooxygenase (COX) enzymes (Chen et al., 1994). Thus, the anti-inflammatory mechanism of action of the active components of the extract would involve PLA2. For this reason we tested the ability of the extract to inhibit PLA2 activity by the indirect radial hemolysis in agar plate method. However, this study showed absence of inhibitory effect on secretor PLA2 activity of $C$. gigantea. These results partially agree with previous studies on the inhibitory activity of PLA2 of various extracts from seaweeds, revealing inhibitory activity only in the extract of Dictyota dentata (Llanio et al., 1998). In contrast, Mayer, in 1993, isolated 12 compounds from seaweeds with powerful inhibitory activity of PLA2 from bee venom. Our results indicate that this study must be extended to other secretor PLA2, including PLA2 from mammals.

We also investigated the antinociceptive activity of the extract in the acetic acid-induced writhing test in mice. The abdominal constriction response induced by acetic acid has been mainly used as screening tool for the assessment of analgesic or anti-inflammatory properties of new agents as well as a typical model for visceral inflammatory pain (Tjølsen, Hole, 1997). The local irritation provoked by a test agent in the intraperitoneal cavity triggers a diversity of mediators, such as bradykinin, substance $\mathrm{P}$ and prostaglandins, particularly PGI2, as well as some cytokines such as IL-1 $\beta$, TNF- $\alpha$ and IL-8 (Correa et al., 1996; Ikeda et al., 2001). These mediators activate chemosensitive nociceptors that contribute to the development of inflammatory pain.

The methanolic extract inhibited significantly the number of writhes suggesting that its antinociceptive effect could be related to inhibition of mediators released in response to acetic acid. Nevertheless, the intraperitoneal route was more effective than oral at inhibiting this response at all evaluated doses $(12.5-100 \mathrm{mg} / \mathrm{kg})$, while only the maximum oral dose $(800 \mathrm{mg} / \mathrm{kg})$ reduced the abdominal constrictions. This result may be due to the limited bioavailability of the active constituents of the extract provoked by a poor absorption or the first-pass effect in liver. According to the test employed, this antinociceptive effect is probably of peripheral origin. We have previously demonstrated the antinociceptive activity of aqueous extract of this seaweed in the same test Frías et al. (2011), although in that study we obtained an effect more potent using oral administration. Inhibition of number of writhes in extracts and components obtained from seaweeds were also demonstrated by Guzmán et al. (2001), Viana et al., (2002) and Frías et al. (2011).

In conclusion, it can be suggested that the methanolic extract from D. obtusata has powerful topical anti-inflammatory and antinociceptive activities. These observed properties could be associated with a probable synergistic effect of the diverse components of methanolic extract. Further studies are required to isolate the active principles 
and to determine the possible mechanism of actions of these compounds and their potential for therapeutic use in the treatment of inflammatory and pain pathologies.

\section{REFERENCES}

ABBAS, A.K.; LITCHMAN, A.H.; PILLAI, S. Inmunología básica y clínica. Philadelphia: Saunders Elsevier, 2008. $215 \mathrm{p}$.

ANANTHI, S.; BALAJI, H.R.; GOPALAN, A.; GAVATHRI, V.; RAMAKRISHNAN, G.; VASANTHI, H.R. In vitro antioxidant and in vivo anti-inflammatory potential of crude polysaccharide from Turbinaria ornate (Marine Brown Alga). Food Chem. Toxicol., v.48, p.187-192, 2010.

ANCA, J.M.; LAMELA, M.; CALLEJA, J.M. Activity on the central nervous system of Himanthalia elongata. Planta Med., v.59, n.3, p.218-220, 1993.

AWAD, N.E. Biologically active steroid from the green alga Ulva lactuca. Phytother. Res., v.14, n.8, p.641-643, 2000.

BLAZSO, G.; GABOR, M. Anti-oedematous action of some Hi-receptor antagonists. Agents Actions, v.42, p.13, 1994.

CHEN, I.L.; GERWICK, W.H.; SCHATZMAN, R.; LANEY, M. Isorawsonol and related IMO dehydrogenase inhibitors from the tropical alga Avrainvillea rawsoni. J. Nat. Prod., v.57, p.947-952, 1994.

CHONG, A.S.F.; PARISH, C.R. Non-immune lymphocyte macrophage interaction II. Evidence that the interaction involves sulfated polysaccharide recognition. Cell Immunol., v.92, n.2, p.277-289, 1985.

CORREA, C.R.; KYKE, D.J.; CHAKRAVERTY, S.; CALIXTO, J.B. Antinociceptive profile of the pseudopeptide B2 bradykinin and receptor antagonist NPC 18688 in mice. $\mathrm{Br}$. J. Pharmacol., v.117, n.3, p.552-558, 1996.

EL GAMAL, A.A. Biological importance of marine algae. Saudi. Pharm. J., v.18, n.1, p.1-25, 2010.

FAULKNER, D.J. Marine natural products. Nat. Prod. Rep., v.19, p.1-48, 2002.

FLOREZ, J.; REIG, E. Terapéutica farmacológica del dolor. Pamplona: Ediciones Universidad de Pamplona, 1994. $331 \mathrm{p}$.
FRIAS, A.I.; DUTOK, C.M.; GARCIA, N.; SUAREZ, A.M.; SANTOS, Y.; CABRERA, H. Anti-inflammatory and analgesic activities of red seaweed Dichotomaria obtusata. Braz. J. Pharm. Sci., v.47, n.1, p.111-118, 2011.

GABOR, M.; RAZGA, Z. Effects of non-steroidal antiphlogistics on mouse ear oedema induced with dithranol. Acta Physiol. Hung., v.75, p.287, 1990.

GANOVSKI, K.H.; SHIPOCHLIEV, T.; BRATOVA, K. Antiinflammatory action of extracts from marine algae collected in the area of Burgas seacoast. Vet. Med. Nauki, v.16, n.7, p.54-61, 1979.

GUSLANDI, M. Nitric oxide and inflammatory bowel diseases. Eur. J. Clin. Invest., v.28, p.904-907, 1998.

GUTIERREZ, J.M.; ÁVILA, C.; ROJAS, E.; CARDAS, L. An alternative in vitro method for testing the potency of polyvalent antivenom produced in Costa Rica. Toxicon., v.26, n.3, 1988.

GUZMÁN, S.; GATO, A.; CALLEJA, J.M. Antiinflammatory, analgesic and free radical scavenging activities of the marine microalgae Chlorella stigmatophora and Phaeodactylum tricornutum. Phytother. Res., v.15, n.3, p.224-230, 2001.

IKEDA, Y.; UENO, A.; NARABA, H.; OH-ISHI, S. Involvement of vanilloid receptor VR1 and prostanoids in the acidinduced writhing responses of mice. Life Sci., v.69, n.24, p.2911-2919, 2001.

JUGDUTT, B.I. Cyclooxygenase inhibition and adverse remodeling during healing after myocardial infarction. Circulation, v.115, p.288-291, 2007.

JUNG, W.; CHOI, I.; OH, S.; PARK, S.W.; SEO, S.K.; LEE, S.W.; LEE, D.S.; HEO, S.J.; JEON, Y.J.; JE, J.Y.; AHN, C.B.; KIM, J.S.; OH, K.S.; KIM, J.M.; MOON, C.; CHOI, I.W. Anti-asthmatic effect of marine red alga (Laurencia undulata) polyphenolic extracts in a murine model of asthma. Food Chem. Toxicol., v.47, n.2, p.293-297, 2009.

KAZLOWSKA, K.; HSU, T.; HOU, CH.-CH.; YANG, J.-CH.; TSAI, G.-J. Anti-inflammatory properties of phenolic compounds and crude extract from Porphyra dentata. $J$. Ethnopharmacol., v.128, p.123-130, 2010.

KOSTER, R.; ANDERSON, M.; DE BEER, E.J. Acetic acid for analgesic screening. Fed. Proc., v.18, p.412, 1959. 
KUMAR, R.; ZI-RONG, X. Biomedical Compounds from Marine organisms. Mar. Drugs, n.2, p.123-146, 2004.

LLANIO, M.; FERNANDEZ, M.D.; CONCEPCION, A.R.; MUSTELIER, E.; CABRERA, B. Pesquisaje de propiedades antiinflamatorias y analgésicas en extractos de origen marino de Cuba. Rev. Cubana Plant. Med., v.3, n.2, p.69-71, 1998.

LUCAS, R.; GIANNINI, C.; D’AURIA, M.V.; PAYÁ, M. Modulatory effect of bolinaquinone, a marine sesquiterpenoid, on acute and chronic inflammatory processes. J. Pharmacol. Exp. Ther., v.304, n.3, p.11721180, 2003.

MAYER, A.M.S.; PAUL, V.J.; FENICAL, W.; NORRIS, J.N.; DE CARVALHO, M. S.; JACOBS, R.S. Phospholipase $\mathrm{A}_{2}$ inhibitors from marine algae. Hidrobiología, v.260/261, n.???, p.521-529, 1993.

NISIZAWA, K.; NODA, H.; KIKUCHI, R.; WATAMABA, T. The main seaweed foods in Japan. Hydrobiol. J., v.151/152, n.1, p.5-29, 1987.

PAYÁ, M.; FERRÁNDIZ, M.L.; SANZ, M.J.; BUSTOS, G.; BLASCO, R.; RIOS, J.L.; ALCARAZ, M.J. Study of the antioedema activity of some seaweed and sponge extracts from the mediterranean coast in mice. Phytother. Res., v.7, p.159-162, 1993.

PRUZANSKI, W.; VADAS, P. Phospholipase $\mathrm{A}_{2}$-a mediator between proximal and distal effectors of inflammation. Immunol. Today, v.12, n.5, p.143-146, 1991.

RODRÍGUEZ, I.I.; SHI, Y.P.; GARCIA, O.J.; RODRIGUEZ, A.D.; MAYER, A.M.; SANCHEZ, J.A.; ORTEGABARRIA, E.; GONZALEZ, J. New pseudopterosin and secopseudopterosin diterpene glycosides from two Colombian isolates of Pseudopterogorgia elisabethae and their diverse biological activities. J. Nat. Prod., v.67, n.10, p.1672-1680, 2004.
SCHLEDE, E.; MISCHKE, V.; ROLL, R.; KAYSER, D. A national validation study of the acute-toxic-class method as alternative to the $\mathrm{LD}_{50}$ test. Arch. Toxicol., v.66, p.45570, 1992 .

SILVA, E.D.; SCHEUER, P.J. Manoalide, an antibiotic sesterterpenoid from the marine sponge Luffariella variabilis (Poleajaeff). Tetrahedron Lett., v.21, n.17, p.1611-1614, 1980.

SMIT, A.J. Medicinal and pharmaceutical uses of seaweed natural products: a review. J. Appl. Phycol., v.16, p.245$262,2004$.

SUÁREZ, A.M. Lista de Macroalgas Marinas. Rev. Invest. Mar., v.26, n.2, p.93-148, 2005.

SUGIURA, Y.; MATSUDA, K.; YAMADA, Y.; NISHIKAWA, M.; SHIOYA, K.; KATSUZAKI, H.; IMAI, K.; AMANO, H. Isolation of a newanti-allergic phlorotannin, phlorofucofuroeckol-B, from an edible brown alga Eisenia arborea. Biosci. Biotech. Biochem., v.70, p.2807-2811, 2006.

TJOLSEN, A.; HOLE, K. Animal models of analgesia. In: The pharmacology of pain. DICKENSON, A.; BESSON, J. (Eds.). Berlín: Verlag, 1997. v.130, p.1-20.

TUBARO, A.; DRI, P.; MELATO, M.; MULAS, G.; BIACHINI, P.; DEL NEGRO, P.; DELLA-LOGGIA, R. In the croton oil ear edema test the effects of non-steroidal anti-inflammatory drugs (NSAIDs) are dependent on the dose irritant. Agents Actions, v.19, p.371-373, 1986.

VIANA, G.S.B.; FREITAS, A.L.P.; LIMA, M.M.L.; VIEIRA, L.A.P.; ANDRADE, M.C.H.; BENEVIDES, N.M.B. Antinociceptive activity of sulfated carbohydrates from the red algae Bryothamnion seaforthii (Turner) Kutz. and B. triquetrum (SG Gmel)M. Howe. Braz. J. Med. Biol. Res., v.35, n.6, p.713-722, 2002.

Received for publication on April 12 $2^{\text {th }}, 2012$ Accepted for publication on September 20 $0^{\text {th }}, 2012$ 